\title{
COMPARATIVE STUDIES ON USING A LOCAL ISOLATE OF BACILLUS THURINGIENSIS IN DIFFERENT GRANULE FORMULATIONS AGAINST COTTON LEAF WORM SPODOPTERA LITTORALIS
}

\author{
MOHAMMAD, ABEER M., ${ }^{1}$ HANAN H. OSMAN ${ }^{1}$ and MAALY H. ALI ${ }^{2}$ \\ 1 Plant Protection Institute, ARC, Dokki, Giza, Egypt \\ 2 King Abdul Aziz Univ., Rabigh, Fac. of science and Arts, Dept. of Biology
}

(Manuscript received 13 December 2011)

\begin{abstract}
A Bacillus thuringiensis isolate (KIII), isolated from Egyptian soil, was produced in liquid culture using yeast extractmolt- glucose medium, where the spore-crystal complexes were recovered. The complexes were formulated into three granule formulations, then the toxicity of the isolate was evaluated in laboratory by bioassay against the cotton leafworm $S$. littoralis. Results exhibited that, the best formulation for keeping biological activity (both efficacy and survival) of $B$. thuringiensis was the alginate granules. Bioassays of the formulation containing Congo red (as UV- protectant), indicate the superiority of this additive to other in improving the effectiveness of B.t. under exposure to sunlight. Also, adding molasses + soybean flour exhibited the highest efficacy when using as feeding stimulants. Zinc sulphate also showed a remarkable effect in enhancing B.t. potency and viability.

Key words: Bacillus thuringiensis, granule formulations, Spodoptera littoralis.
\end{abstract}

\section{INTRODUCTION}

Commercial formulations containing $B$. thuringiensis are applied as dry sprayable preparations, which suffer from a lack of residual insecticidal activity caused by washoff by rainfall or degradation by sunlight. Also, these preparations are not palatable to insects, thus limiting their effectiveness (Gillespie et. al., 1994). A variety of responses to the UV spectrum by $B$. thuringiensis have been observed including inactivation of spores at $330 \mathrm{~nm}$ (Griego \& Spence, 1978) and crystal inactivation caused by tryptophan destruction (Pozsgay et. al.,1987). Encapsulated spores and crystals of B.t. with congored or folic acid as UV screens exhibited moderate spore viability and retained at least $50 \%$ of their toxicity for 2 weeks (Dunkle \& Shasha, 1989). Also, coax, molasses, sucrose and soybean flour were used as feeding stimulants or adjuvants to increase the potency of B.t. (Hafez et. al., 1987). The objective of this 
research was to select a formulation to extent the insecticidal activity and viability of B. thuringiensis isolate for the control of cotton leafworm S. littoralis.

\section{MATERIALS AND METHODS}

\section{Bacillus thuringiensis strain.}

B. thuringiensis KIII local isolate was obtained by isolation from soil in Kaliobiya Governorate, Egypt (Mohammad, 2010).

\section{Propagation of $B$. thuringiensis spore-crystal complex.}

$B$. thuringiensis KIII isolate was propagated on a modified yeast extract- moltglucose medium containing yeast extract $(0.5 \%)$, malt extract $(0.5 \%)$, tryptone $(0.5 \%)$, peptone $(0.5 \%)$, glucose $(0.5 \%)$, and $\mathrm{KH}_{2} \mathrm{PO}_{4} .7 \mathrm{H}_{2} \mathrm{O}(0.1 \%)$. Fermentation was done using the method of Nickerson et. al., 1974. The spore-crystal paste, which obtained from the culture by centrifugation, was stored at $5^{\circ} \mathrm{C}$ until used.

\section{Encapsulation procedures.}

Three groups of experiments were done to achieve the effectiveness of $B$. thuringiensis using different granule formulations. The first, starch granules consists of: refined corn oil $(2 \mathrm{~g})$ was mixed with pregelatinized starch powder $(25 \mathrm{~g})$. Chilled $\left(2^{\circ} \mathrm{C}\right)$ distilled water $(60 \mathrm{ml})$, containing a suspension of B.t. spores and crystals at the desired concentration, is stirred into the starch oil mixture, forming a gelatinous mass in 10-15 s. This mixture was allowed to stand for $30 \mathrm{~min}$ at room temperature, producing nonsticky mass which is then processed in a blender with $25 \mathrm{~g}$ pearl starch powder to yield particles pass a 14 -mesh screen $\approx(1.4 \mu \mathrm{m})$. After air drying $24 \mathrm{~h}$, the particles were sieved. The resulting particles contain B.t. spores and crystals entrapped within starch matrix surrounded by a thin coating of starch (Dunkle \& Shasha, 1988).

The second granule formulation: alginate granules, which consists of calcium alginate, $5 \mathrm{~g}$, talc powder, $3.5 \mathrm{~g}$, powdered milk, $9.5 \mathrm{~g}$ and $B$. thuringiensis sporecrystal extract till reach the desired concentration. The previous constituents were mixed together then $50 \mathrm{ml}$ of distilled water $\left(80^{\circ} \mathrm{C}\right)$ were added, the mixture was moved to a bowel containing $500 \mathrm{ml}$ of 0.05 calcium chloride solution $\left(10^{\circ} \mathrm{C}\right)$. The mixture was kept at room temperature for 1 hour to obtain gel, then was filtrated and washed with $1 \mathrm{~L} d$. water to remove the calcium chloride. The gel was cut with spatula and let to dry overnight, and then the particles were sieved (Prabakaram \& Hoti, 2008).

The third formulation was the encapsulated B.t. which consists of: $100 \mathrm{~g}$ powdered sugar, $100 \mathrm{~g}$ corn flour, $5 \mathrm{ml}$ corn oil, B. thuringiensis spore- crystal extract 
(till reach the desired concentration), $70 \mathrm{ml} \mathrm{d}$. water and $30 \mathrm{ml}$ isopropanol. These were mixed with a spatula, allowed to set for $30 \mathrm{~min}$, and then passed through a 20mesh sieve. The granules were allowed to dry at room temperature. (Tamez-Guerra et. al., 1998).

\section{Using of ultraviolet screens.}

The following materials were selected as UV protectants: congo red, folic acid, charcoal and crude cottonseed oil. The UV protectants were incorporated at the initial preparation step as aqueous suspensions at $0.1 \%$.

\section{Sunlight exposure.}

The granulated B.t. was exposed directly to sunlight in containers, each containing $5 \mathrm{~g}$ sample, and were placed on holders in an outdoor area that received sunlight exposure through June and July. The containers were open at the top and had nylon fabric as a cover to facilitate air movement and minimize heat built-up.

\section{Potentiation of B.t. using feeding stimulants.}

The formulation of granulated B.t. was developed by adding some ingredients to select one highly palatable to the larvae, and so high potency of the formulation. The selected ingredients were molasses, (5\%), fresh maize leaves and soybean flour $(5 \%)$. Formulations then were evaluated by mortality bioassay and viability tests.

\section{Potentiation of B.t. using chemical additives.}

Some chemical additives have been added to extent the activity of B.t. endotoxin. Certain criteria were considered for instance, the compound must be non-toxic to man or animal, no harmful effect on plants, biodegradable and commonly available at low price. These compounds are inorganic salts (calcium carbonate $(0.1 \%)$ \& zinc sulphate $(0.05 \%)$ ), amino acids (alanine, serine, glutamic acid and tryptophan) and urea $(0.5 \%)$.

\section{Leaf bioassay.}

Bioassays on castor leaves were conducted with $2^{\text {nd }}$ instars of Spodoptera littoralis. Susceptible strain of the cotton leafworm Spodoptera littoralis (Boisd), which was reared in the laboratory for several generations away from any insecticide contamination, was used in toxicity tests to evaluate the efficacy of the isolated B.t. in different formulations.

The different formulations were bioassayed against Spodoptera littoralis, according to (Makkar and El Mandrawy, 1996), under their preferable natural conditions. For testing the effectiveness of the bacterial isolate, fresh castor oil leaves were washed with tap water followed by rinsing in sterile water and then left to dry for 10 minutes. Plant leaves were put in bacterial preparation containing $4 \times 10^{8} \mathrm{cfu} / \mathrm{gm}$. The tested plant leaves were then placed into glass jars. Ten larvae $\left(2^{\text {nd }}\right.$ instars $)$ were put in 
each jar, then the jars were placed at room condition held at $27^{\circ} \mathrm{C} \pm 2^{\circ} \mathrm{C}$ for 7 days. Three replicates were used for each concentration. For control, plant leaves were treated with distilled water only. Assessment of larval mortalities was expressed as corrected percentage of total larvae of each treatment, as well as in the control, after 2 up to 7 days daily. Corrected mortality was calculated according to Abbott's formula ( Abbott, 1925), as follows :

Corrected mortality $(\%)=(T-C) /(100-C) \times 100$

Where, $\mathrm{T}=$ No. of dead larvae in treated replicates.

$\mathrm{C}=$ No. of dead larvae in control replicates.

$$
\mathrm{LC}_{50}=\text { the lethal concentration that kills } 50 \% \text { of larval individuals. }
$$

- For potency bioassays, use the $\mathrm{LC}_{50}$ records in the potency formula (Dulmage et. al., 1971)

$$
\frac{\mathrm{LC}_{50} \text { standard }}{\mathrm{LC}_{50} \text { sample }} \times \mathrm{IU} \mathrm{mg}^{-1} \text { standard }=\text { sample } \mathrm{IU} \mathrm{mg}^{-1}
$$

\section{Spore viability.}

In order to determine the spore survival in different formulations, which were kept at room temperature for different incubation periods, B.t spores were liberated from $10 \mathrm{~g}$ sample of each formulation type, diluted $\left(10^{-1}-10^{-7}\right)$ with sterile distilled water and transferred to nutrient agar. As a control, unformulated B.t extract was similarly diluted and plated. Samples were incubated at $28^{\circ} \mathrm{C}$ for $36 \mathrm{hr}$, the colonies were counted. The same test was repeated after 2 and 6 months to study the spore survival in formulations.

\section{RESULTS AND DISCUSSION}

\section{Efficacy of formulation type.}

In this experiment, castor bean leaves were used for testing efficacy of three different granule formulations against $2^{\text {nd }}$ instars of $S$. littoralis, by leaf bioassays. Efficacy was tested, with consideration of that, the concentration of B.t. spores (cfu/gm) was instant in all formulations. Data represented in Table (1) showed that, the plant leaf assays gave a good indication of how the formulations protect insecticidal activity of $B$. thuringiensis compared with unformulated spore-crystal complexes. 
The results obtained in (Table 1 ) revealed that, there were differences in the efficacy of different formulation types. Alginate granules represented the highest efficacy followed by starch granules then the encapsulated B.t., the high efficacy of alginate granules may be due to the protecting effect of the product for the bacterium from being faced directly with the microbial degradation agents.

Data in Table (1) showed the $\mathrm{LC}_{50}$ values of different formulations of $B \cdot t$. against the $2^{\text {nd }}$ instars of $S$. littoralis. Alginate granules represented the highest efficacy with $\mathrm{LC}_{50}$ $=79.2 \times 10^{4} \mathrm{cfu} / \mathrm{gm}$, then starch granules represented $\mathrm{LC}_{50}=99.3 \times 10^{4} \mathrm{cfu} / \mathrm{gm}$, while $\mathrm{LC}_{50}$ of encapsulated B.t. $=119.8 \times 10^{4} \mathrm{cfu} / \mathrm{gm}$.

Also, there were clear differences in slope values (b) and potency between the three tested formulations. The slope values ranged between 0.201 and 0.883 .

Table 1. Effect of different granule formulations on the efficacy of $B$. thuringiensis KIII isolate against Spodoptera littoralis larvae.

\begin{tabular}{|l|c|c|c|c|}
\hline Formulation type & $\begin{array}{c}\mathrm{LC}_{50} \\
\mathrm{cfu} \times 10^{4} / \mathrm{gm}\end{array}$ & $\begin{array}{c}\text { Potency } \\
\mathrm{IU} / \mathrm{mg}^{*}\end{array}$ & slope & $\begin{array}{c}\mathrm{LC}_{50} \\
\text { B.t.kurstaki } \\
\mathrm{cfu} \times 10^{4} / \mathrm{gm}\end{array}$ \\
\hline Alignate granules & 79.2 & 14141 & 0.498 & 70.0 \\
\hline Starch granules & 99.3 & 14500 & 0.274 & 90.0 \\
\hline Encapsulated B.t. & 119.8 & 13355 & 0.201 & 100.3 \\
\hline Unformulated B.t. & 183.4 & 10643 & 0.883 & 122.1 \\
\hline
\end{tabular}

*Based on an assigned B.t.kurstaki potency of $16,000 \mathrm{IU} / \mathrm{mg}$.

These results are in line with those obtained by Prabakaram \&Hoti, 2008 who used alginate for encapsulating B.t. in order to control release of spores and crystals to kill mosquitoes in the field. While, Dunkle \& Shasha (1988) demonstrated that the starch matrix system can be used successfully to microencapsulate $B$. thuringiensis, which maintained its biological activity over an extended period of time.

\section{Using of ultraviolet screens.}

Alginate granule samples, which were used containing UV-protectants (1\%), were assayed against larvae of Spodoptera littoralis while exposed to natural sunlight. All, experiments indicated that, the $B . t$. granules formulated with UV-protectants exhibited increase in efficacy compared with that which contains no UV-protectants (Table 2). The granules of B.t. formulated with congo red exhibited the highest efficacy. Also, B.t. formulated with folic acid had a similar, but somewhat lower. The $\mathrm{LC}_{50}$ values were 70.1 and $70.4 \times 10^{4} \mathrm{cfu} / \mathrm{gm}$, respectively. While, formulations 
containing charcoal or cotton seed oil exhibit lower toxicity with $L_{50}$ values $=79.1 \mathrm{x}$ $10^{4} \mathrm{cfu} / \mathrm{gm}$.

Casein and gluten have been shown to be more effective with smaller amounts when used for resistance to UV irradiation (Behle, et. al., 1996).

Table 2. Effect of some additives as ultraviolet screens on the efficacy of $B$. thuringiensis KIII isolate against Spodoptera littoralis larvae.

\begin{tabular}{|l|c|c|c|c|}
\hline Additive material & $\begin{array}{c}\mathrm{LC}_{50} \\
\mathrm{cfu} \times 10^{4} / \\
\mathrm{gm}\end{array}$ & $\begin{array}{c}\text { Potency } \\
\mathrm{IU} / \mathrm{mg}^{*}\end{array}$ & slope & $\begin{array}{c}\mathrm{LC}_{50} \\
\text { B.t.kurstaki } \\
\mathrm{cfu} \times 10^{4} / \mathrm{gm}\end{array}$ \\
\hline Congo red & 70.1 & 14171 & 0.94 & 62.1 \\
\hline Folic acid & 70.4 & 13636 & 1.01 & 60.3 \\
\hline Charcoal & 79.1 & 14177 & 1.13 & 71.0 \\
\hline Cotton seed oil & 79.1 & 14177 & 1.02 & 71.0 \\
\hline
\end{tabular}

*Based on an assigned B.t.kurstaki potency of $16,000 \mathrm{IU} / \mathrm{mg}$.

Also, El-Sharkawey et. al., 2009 used several antioxidant materials (vitamin A, vitamin $\mathrm{C}$, vitamin $\mathrm{E}$ and selenium) in protecting $B$. thuringiensis against inactivation by solar irradiation. They demonstrated that, these materials prolonged the residual insecticidal activity of $B$. thuringiensis against the potato tuber moth larvae.

\section{Feeding stimulants.}

In this experiment molasses (5\%), fresh maize leaves $(5 \%)$, soybean flour $(5 \%)$ and their combinations were used to fined eliciting materials to evaluate their role in increasing the potency of B.t. formulations expecting that these materials will make it more palatable to the target insect and so increase feeding response. Results in Table (3) indicated that, formulation containing molasses + soybean flour led to a better acceptability as compared with the other additives. The efficacy of this formulation showed an increase in efficacy with $\mathrm{LC}_{50}=60.9 \times 10^{4} \mathrm{cfu} / \mathrm{gm}$. Adding fresh maize leaves + soybean flour indicated $L C_{50}=69.6 \times 10^{4} \mathrm{cfu} / \mathrm{gm}$. Then molasses + fresh maize leaves gave the same result with adding soybean flour only ( $L_{50}=$ $71.4 \times 10^{4} \mathrm{cfu} / \mathrm{gm}$ ). While adding only molasses or fresh maize leaves did not show any increase in efficacy. Based on similar studies Garcia et. al., 2009 designed a B.t. based formulation increased feeding preference on $S$. exigua larvae. The corn starch formulation modified by gelatin and dried corncob was the most preferable by the larvae and so the good efficacy results. While, Gillespie et. al., 1994 determined the palatability of several formulations, they found that, the larvae of corn borer 
preferred B.t. granules containing cotton leaves or the feeding stimulant coax. While, rejected granules formulated with $\mathrm{CaCl}_{2}$.

Table 3. Effect of some additives as feeding stimulants on the efficacy of $B$. thuringiensis KIII isolate against Spodoptera littoralis larvae.

\begin{tabular}{|l|c|c|c|c|}
\hline Additive material & $\begin{array}{c}\mathrm{LC}_{50} \\
\mathrm{cfu} \times 10^{4} / \\
\mathrm{gm}\end{array}$ & $\begin{array}{c}\text { Potency } \\
\text { IU/mg* }\end{array}$ & slope & $\begin{array}{c}\mathrm{LC}_{50} \\
\text { B.t.kurstaki } \\
\text { cfu x 10\% } / \mathrm{gm}\end{array}$ \\
\hline 1- Molasses (5\%) & 79.0 & 14177 & 1.12 & 70.0 \\
\hline 2- Fresh maize leaves & 79.0 & 14177 & 0.81 & 70.1 \\
\hline 3-Soybean flour (5\%) & 71.5 & 13333 & 0.70 & 60.1 \\
\hline 4- (1+3) & 60.9 & 13115 & 1.50 & 50.2 \\
\hline 5- (2+3) & 69.6 & 13793 & 2.30 & 60.0 \\
\hline 6- $(1+2)$ & 71.4 & 13669 & 1.55 & 61.1 \\
\hline
\end{tabular}

*Based on an assigned B.t.kurstaki potency of $16,000 \mathrm{IU} / \mathrm{mg}$.

\section{Chemical additives.}

In this set of experiments some chemical materials have been developed to overcome the short persistence of B.t. and in the same time to extend the activity of B.t. These chemicals included inorganic salts (calcium carbonate $(0.1 \%)$ and zinc sulphate $(0.05 \%)$ ), amino acids (alanine, serine, glutamic acid and tryptophan) and urea $(0.5 \%)$.

The results obtained in Table (4) showed that, calcium carbonate enhanced the efficacy of B.t. KIII against larvae of Spodoptera littoralis. This may be attributed to the fact that the addition of such salt will change $\mathrm{pH}$ of the gut, being more alkaline and thus enhancing the endotoxin breakdown and release of toxic fragments. Also, zinc sulphate showed a remarkable effect in enhancing B.t. potency. The mode of action of this salt may be correlated to its effect on the proteolytic enzymes present in the insect midgut and also enhancing the stability of both spores and crystals against $\mathrm{pH}$ and also UV irradiation (Salama et. al., 1985). The alginate granules which contain $\mathrm{ZnSO}_{4}$ resulted in maximum larvicidal activity with $\mathrm{LC}_{50}=40.6 \times 10^{4} \mathrm{cfu} / \mathrm{gm}$.

With amino acids (Table 4) tryptophan and serine enhanced the potency of B.t. KIII against the larvae with $\mathrm{LC}_{50}=49.9$ and $49.1 \times 10^{4} \mathrm{cfu} / \mathrm{gm}$, respectively. The mode of action of these additives may be correlated to their effect in increasing the endotoxin solubility in the insect gut (Salama et. al., 1985). While adding urea gave the lowest activity against the larvae with $\mathrm{LC}_{50}$ of $70.1 \times 10^{4} \mathrm{cfu} / \mathrm{gm}$. 
Table 4. Effect of some chemical additives on the efficacy of B. thuringiensis KIII isolate against Spodoptera littoralis larvae.

\begin{tabular}{|l|c|c|c|c|}
\hline Additive material & $\begin{array}{c}\mathrm{LC}_{50} \\
\mathrm{cfu} \times 10^{4} / \\
\mathrm{gm}\end{array}$ & $\begin{array}{c}\text { Potency } \\
\mathrm{IU} / \mathrm{mg}^{*}\end{array}$ & slope & $\begin{array}{c}\mathrm{LC}_{50} \\
\text { B.t.kurstaki } \\
\text { cfu } \times 10^{4} / \mathrm{gm}\end{array}$ \\
\hline \multicolumn{1}{|c|}{ Zinc Sulphate } & 40.6 & 14141 & 1.23 & 35.1 \\
\hline $\begin{array}{c}\text { Calcium } \\
\text { carbonate }\end{array}$ & 52.3 & 15296 & 1.24 & 50.0 \\
\hline Alanine & 62.0 & 15484 & 0.71 & 60.2 \\
\hline Serine & 49.1 & 13035 & 0.92 & 40.0 \\
\hline Glutamic acid & 66.0 & 14545 & 1.03 & 60.1 \\
\hline Tryptophan & 49.9 & 13974 & 1.78 & 40.2 \\
\hline Urea (0.5\%) & 70.1 & 13833 & 2.02 & 62.0 \\
\hline
\end{tabular}

*Based on an assigned B.t.kurstaki potency of $16,000 \mathrm{IU} / \mathrm{mg}$.

\section{Effect of different additives on efficacy of B.t. after 6 months post preparation.}

The effect of alginate granules with some additives as UV-protectant or feeding stimulants on efficacy of B.t. after 6 months post preparation, was presented in Table (5). The results obtained in this table indicate that, the alginate granules which contain $\mathrm{ZnSO}_{4}$ was the best formulation for keeping the activity of B.t. after 6 months post preparation. The decrease in activity was only $7.1 \%$. While, the granules which contain congo red revealed the highest decrease in activity with $24 \%$ after 6 months.

Table 5. Effect of different additives on activity of B. thuringiensis KIII after 6 months post preparation.

\begin{tabular}{|c|c|c|c|c|c|}
\hline \multirow[t]{2}{*}{ Formulation type } & \multicolumn{2}{|c|}{$\begin{array}{c}\mathrm{LC}_{50} \\
\text { cfu } \times 10^{4} / \mathrm{gm}\end{array}$} & $\begin{array}{l}\text { potency } \\
\text { IU/mg* }\end{array}$ & slope & $\begin{array}{c}\mathrm{LC}_{50} \\
\text { B.t. kurstaki } \\
\text { cfu } \times 10^{4} / \\
\text { am }\end{array}$ \\
\hline & $\begin{array}{l}\text { Zero } \\
\text { time }\end{array}$ & \multicolumn{4}{|c|}{ After 6 months } \\
\hline $\begin{array}{ll} & \text { Alignate granules } \\
\end{array}$ & 79.2 & 89.4 & 14384 & 0.362 & 80.0 \\
\hline$(\mathrm{Ag})+$ congo red & 70.1 & 92.1 & 15288 & 0.256 & 88.0 \\
\hline $\begin{array}{l}(\mathrm{Ag})+(\text { molasses }+ \text { soy } \\
\text { bean flour })\end{array}$ & 60.9 & 71.1 & 16814 & 1.220 & 64.1 \\
\hline$(\mathrm{Ag})+\mathrm{ZnSO}_{4}$ & 40.6 & 48.6 & 13333 & 2.470 & 33.1 \\
\hline
\end{tabular}

*Based on an assigned B.t.kurstaki potency of $16,000 \mathrm{IU} / \mathrm{mg}$. 


\section{Spore viability.}

The effect of different formulations on spore viability, stored at room temperature, was checked after 2 and 6 months post- preparation, by standard bacteriological plating techniques. Viable spores, based on those counts, indicated the effect of the process of formulation and storage period on the spore viability.

Results in Table (6) show that, the best formulation for keeping the viability of B.t. spores, was the alginate granules with the feeding stimulants (molasses + soybean flour). While the B.t. granules without additives was the lowest for keeping the spores survived throughout the tested period. The decrease in spore viability, from zero time to 6 months after preparation was as follows:

- After 2 months post -preparation, the decrease of viability was $47 \%$ with alginate granules + feeding stimulants, followed by the alginate granules with $\mathrm{ZnSO}_{4}$ (the decrease in viability was $55 \%$ ). While the decrease in viability of granules which did not contain additives was $76 \%$.

- After 6 months post- preparation: Alginate granules were used with or without different additives, were also tested for spore viability after 6 months post preparation. Results indicated that, $B$. thuringiensis spores that were alginate granulated but which did not contain any additives became inactivated rapidly. Subsequent comparisons were made with formulation containing different additives. Results in Table (6), indicated that, spore viability remained higher when feeding stimulants (molasses + soybean flour) were added to the formulation. The decrease in spore viability after 6 months was $68 \%$. Also, adding of zinc sulphate kept the viability after 6 months hence the granules which contained this salt had viability decrease in spore counts $(70 \%)$. While the decrease in viable spore counts with granules without additives was $97 \%$.

Table 6. Effect of different granule formulations on spore viability of $B$. thuringiensis.

\begin{tabular}{|l|c|c|c|c|c|}
\hline \multirow{2}{*}{ Formulation type } & \multicolumn{5}{|c|}{ Spore viability (CFU/gm), after } \\
\cline { 2 - 6 } & $\begin{array}{c}\text { Zero } \\
\text { time }\end{array}$ & 2 months & $\begin{array}{c}\% \\
\text { decrease }\end{array}$ & $\begin{array}{c}6 \\
\text { monthes }\end{array}$ & $\begin{array}{c}\% \\
\text { decrease }\end{array}$ \\
\hline $\begin{array}{l}\text { Alignate granules } \\
(\mathrm{Ag})\end{array}$ & $4 \times 10^{8}$ & $9.6 \times 10^{7}$ & 76 & $1 \times 10^{7}$ & 97 \\
\hline $\mathrm{Ag}+$ congo red & $4 \times 10^{8}$ & $9.8 \times 10^{7}$ & 75 & $1 \times 10^{7}$ & 97 \\
\hline $\begin{array}{l}\mathrm{Ag}+(\text { molasses }+ \text { soy } \\
\text { bean flour) }\end{array}$ & $4 \times 10^{8}$ & $2.1 \times 10^{8}$ & 47 & $8.8 \times 10^{7}$ & 68 \\
\hline $\mathrm{Ag}+\mathrm{ZnSO}_{4}$ & $4 \times 10^{8}$ & $1.8 \times 10^{8}$ & 55 & $6.9 \times 10^{7}$ & 70 \\
\hline
\end{tabular}

These data are in line with those obtained by Pozsgay et. al., 1987 who demonstrated that, no insect toxicity was observed in samples in which there also was no spore 
viability, supporting the hypothesis that solar radiation inactivates the crystals as well as spores. Also, Dunkle \& Shasha (1989) reported that, formulations of $B$. thuringiensis spores and crystals encapsulated together within a starch matrix containing UV screens (congo red) exhibited significant spore viability and retained at least $50 \%$ of their original toxicity after $12 \mathrm{~d}$.

While, Prabakaram \& Hoti, 2008, reported that, calcium alginate granules had disadvantage when contact with phosphate of potassium ions rich in the larval habitats. To overcome these problems, they used different multivalent counterions such zinc sulphate, cobalt chloride and ferric chloride.

\section{REFERENCES}

1. Abbott, W. S. 1925. A method of computing the effectiveness of an insecticide. J. Econ. Entomol.18, 265-267.

2. Behle, R. W., M. R. McGuire and B. S. Shasha. 1996. Extending the residual insecticidal activity of $B$. thuringiensis with casein-based formulations. J. Econ. Entomol. 89(7): 1399-1405.

3. Dulmage, H. T., J. A. Correa and A. J. Martinez. 1971. Coprecipitation with lactose as means of recovering the spore-crystal complex of Bacillus thuringiensis. J. Invertebr. Pathol. 15, 15-20.

4. Dunkle, R. L. \& B. S. Shasha. 1988. Starch-encapsulated Bacillus thuringiensis. A potential new method for increasing environmental stability of entomopathogens. Environ. Entomol. 17(1): 120-126.

5. Dunkle, R. L. \& B. S. Shasha. 1989. Response of starch-encapsulated Bacillus thuringiensis containing ultraviolet screens to sunlight. Environ. Entomol. 18(6): 1035-1041.

6. El-Sharkawey, Asmaa, Z., M. Ragaei, M.M. Sabbour, A. H. Abdel-Latif and Rasha Samy. 2009. Laboratory evaluation of antioxidants as UV-protectants for Bacillus thuringiensis against potato tuber moth larvae. Australian Journal of Basic and Applied Sciences, 3(2): 358-370.

7. Garcia, N. R., M. J. Mendoza and J. A. Ortega. 2009. Design of a Bacillus thuringiensis- Based formulation that increases feeding preference on $S$. exigua larvae. J. Econ. Entomol. 102 (1): 58-63.

8. Gillespie, R.L., M. R. McGuire and B. S. Shasha. 1994. Palatability of flour granular formulations to European corn borer larvae. J. Econ. Entomol. 87:452457. 
9. Griego, V. M. and K. D. Spence. 1978. Inactivation of Bacillus thuringiensis spores by ultraviolet and visible light. Appl. Environ. Microbiol. 35: 906-910.

10. Hafez, H., H. S., Salama, R. Abott-Ela and M. R. Ragaei. 1987. Evaluation of adjuvants for use with Bacillus thuringiensis vs. Heliothes armigera. Z. ang. Ent. 103: 313-319.

11. Makkar, A. W. and Mona, B. R. El Mandrawy. 1996. Laboratory studies for increasing the efficacy of a bioinsecticide against Spodoptera littoralis larvae. Annals of Agric. Sci., Moshtohor, 34(4), 1925-1943.

12. Mohammad, M. Abeer. 2010. Isolation of Bacillus thuringiensis from Different Soil Localities in Egypt. Egypt J. Biol. Pest Control, 20(2): 121-125.

13. Nickerson, K.W., G. St. Julian and L. A. Bulla. 1974. Physiology of spore forming bacteria associated with insects: radio respirometric survey of carbohydrate metabolism in the 12 serotypes of Bacillus thuringiensis. Appl. Microbiol. 28:129-132.

14. Pozsgay, M. P., F. H. Kaplan and P. R. Garey. 1987. The effect of sun light on the protein crystals from Bacillus thuringiensis var kurstaki and NRD 12 : a raman spectroscopic study. J. Invertebr. Pathol. 50: 246-253.

15. Prabakaram, G. and L. Hoti. 2008. Immobilization of alginate-encapsulated Bacillus thuringiensis var. israelensis containing different multivalent counterions for mosquito control. Curr. Microbiol. 57: 111-114.

16. Salama, H.S., M. S. Foda and A. Sharaby. 1985. Potential of some chemicals to increase the effectiveness of Bacillus thuringiensis. Z. ang. Ent. 100, 425-433.

17. Tamez-Guerra, P., R. C. Franco, H. M. Roldan, M. R. McGuire and H. A. Olvera. 1998. Laboratory and field comparisons of strains Bacillus thuringiensis for activity against Noctuid larvae using granule formulations. J. Econ. Entomol. 91 (1): 86-93. 


\section{Bacillus thuringiensis دراسات مقارنة على استخدام عزلة محلية لبكتيريا}

\section{Spodoptera littoralis في مستحضرات حبيبية ضد دودة ورق القطن}

$$
\begin{aligned}
& \text { عبير محمود محمد1 ، حنان حبين عثمان } 1 \text { ، معالي حسن علي2 } \\
& \text { 1- قسم بحوث دودة ورق القطن - معطد بحوث وقاية النباتات - مركز البحوث الزراعية }
\end{aligned}
$$



أجريت دراسة على عزلة بكتيرية B.t. ، حيث تم تحضير 3 مستحضرات حبييية مختلفة و تم اختبار فعاليتها ضد يرقات دودة ورق القطن حيث اثتبت النتائج ان مستحضر حبيبات الالجينات هو أفضل

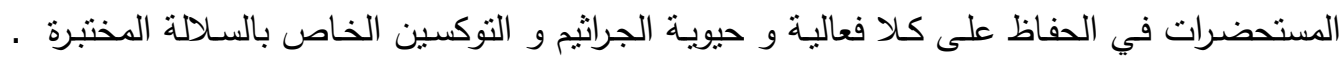
كذلك اثتتت بعض الاضافات فعاليتها في زيادة كفاءة المستحضر مثل الكونجو ريد كمادة حامية ضد الاشعة فوق البنفسجية و كذلك خلبط المولاس و دقيق فول الصويا كمادة جاذبة غذائية و كذا اضافة



